\title{
A survey by questionnaire of psychiatric disturbance in patients attending a venereal diseases clinic
}

\author{
J. R. PEDDER AND D. P. GOLDBERG \\ From the Academic Department of Psychiatry, Middlesex Hospital, and the Institute of Psychiatry, London
}

THIs paper presents the findings from a survey by questionnaire of psychiatric disturbance in a series of just under 300 consecutive new patients attending James Pringle House, the venereology clinic of the Middlesex Hospital, London.

Most previous psychiatric studies from venereology departments in England have been concerned with some specific aspect of psychiatric disturbance.

Several (Macalpine, 1957; Gibbens and Silberman, 1960; Kite and Grimble, 1963) have drawn attention to morbid fears of venereal disease, or vencreophobia, among a large proportion of patients-anything up to one-third-who have no venereal disease. In some cases in this group, the fear of venereal disease may be the presenting symptom of a severe depressive condition (Pedder, 1970). Other reporis have commented on the high incidence of drug abuse (Linken, 1968) and the low motivation for change among homosexuals attending such clinics (Fluker, 1966).

So far there have been no systematic studies of the overall incidence of psychiatric disturbance. To carry out such a survey by psychiatric interview of every new patient would be unreasonable, and a high refusal rate in such a clinic would be probable. Questionnaire methods both facilitate this task and allow each patient's degree of disturbance to be measured.

Various questionnaires have been used to identify psychiatrically disturbed respondents, the most widely used in the English speaking world probably being the Cornell Medical Index. Unfortunately it has the disadvantage that it misses as many as 30 per cent. of known psychiatric patients (Shepherd, Cooper, Brown, and Kalton, 1966), and in common with many other questionnaires in this field does not distinguish sufficiently between personality traits and current symptomatology.

The questionnaire used in this study is the General Health Questionnaire (GHQ), which has been developed recently by one of us in order to overcome

Read at the IUVDT Congress in Budapest on June 16, 1969 Received for publication September 3, 1969 some of these problems (Goldberg, 1969). It is a selfadministered questionnaire aimed at psychiatric caseidentification that takes 10 to 15 minutes to complete, and consists of sixty questions dealing with current feelings and behaviour. The patient scores one for each symptom that he has recently experienced, so that the total score ranges between 0 and 60 . It is in no sense a personality test, but gives a measure of each respondent's degree of non-psychotic psychiatric illness at the time it is completed. It has been validated both in a general practice setting and in the Medical Out-patients Department of a general hospital. The scores have been shown to correlate well $(+0 \cdot 8)$ with an independent assessment by a psychiatrist, and it identifies 95 per cent. of patients who are found at interview to be psychiatrically disturbed.

\section{Method}

Questionnaires were placed by the reception staff in the notes of all new patients. They were handed to the patients by the clinic doctors at the initial interview, and completed in the department while the patients waited for the results of investigations. One month later the notes of all the patients were examined. Details were extracted of data such as age, sex, civil status, occupation, nationality, and diagnosis, as well as possibly less accurate data relating to the complaint and the sexual partner. The questionnaires were scored and all the data then transferred to punched cards.

\section{Results}

219 patients completed the questionnaire. This figure represents 78 per cent. of the 281 new patients who attended the department during the period of the survey. Of the 22 per cent. who did not complete questionnaires, 7 per cent. were foreigners speaking insufficient English, and the remainder (15 per cent.) failed to co-operate.

The scores of groups of patients can be handled in two ways: one can compare the mean scores of diffcrent groups, or one can compute the percentage of 
probable cases in each group, where a probable case is a respondent with a score of 12 or above. For the total population completing the GHQ, the mean score was 9.94 (standard deviation $=5.9$ ), and the percentage of probable cases was 29.7 per cent. All subsequent between-group comparisons have been made by considering the mean scores of the various groups, but the percentage of probable cases has also been shown.

Table I shows the difference between the sexes. The mean score for women is significantly higher than that for men $(P<0.01)$.

TABLE I Sex

\begin{tabular}{lccc}
\hline Sex & & Male & Female \\
\cline { 1 - 1 } \cline { 4 - 4 } Total number of patients & & 148 & 71 \\
Mean score on questionnaire & & 8.6 & $12 \cdot 8$ \\
Percentage potential psychiatric cases & & 23.6 & 42.3 \\
\hline
\end{tabular}

Table II shows the variation of scores with age. Although there is a trend for the scores to rise with age from 20 to 59 years, it is not consistent over the whole age range, since the teenage population is distinguished by having fairly high scores. Although there were only six patients over 50 years of age, it is interesting to note that five of them were probable psychiatric cases. The observation needs to be repeated on a larger sample.

\begin{tabular}{|c|c|c|c|c|c|}
\hline Age (decades) & $<20$ & $20-29$ & $30-39$ & $40-49$ & $50+$ \\
\hline \multirow{3}{*}{$\begin{array}{l}\text { Total number } \\
\text { of patients } \\
\text { Mean score on } \\
\text { questionnaire } \\
\text { Percentage potential } \\
\text { psychiatric cases }\end{array}$} & 19 & 134 & 40 & 19 & 6 \\
\hline & $13 \cdot 2$ & $9 \cdot 0$ & $9 \cdot 9$ & $11 \cdot 7$ & $16 \cdot 5$ \\
\hline & $52 \cdot 7$ & $23 \cdot 1$ & 30.0 & $36 \cdot 8$ & $83 \cdot 3$ \\
\hline
\end{tabular}

Table III gives the variation of scores by social class $^{\star}$, showing students and housewives separately.

^Registrar General's classification

TABLE III Social class

\begin{tabular}{|c|c|c|c|c|c|c|c|}
\hline Social class & $I$ & $I I$ & $I I I$ & $I V$ & $V$ & Students & Housewives \\
\hline $\begin{array}{l}\text { Total number of patients } \\
\text { Mean score on questionnaire } \\
\text { Percentage potential psychiatric cases }\end{array}$ & $\begin{array}{l}14 \\
5 \cdot 1 \\
7 \cdot 1\end{array}$ & $\begin{array}{l}58 \\
9 \cdot 0 \\
24 \cdot 1\end{array}$ & $\begin{array}{r}91 \\
9 \cdot 9 \\
30 \cdot 7\end{array}$ & $\begin{array}{l}23 \\
13 \cdot 7 \\
43 \cdot 3\end{array}$ & $(-)$ & $\begin{array}{l}24 \\
10 \cdot 0 \\
33 \cdot 3\end{array}$ & $\begin{array}{l}5 \\
(20 \cdot 5) \\
(80)\end{array}$ \\
\hline
\end{tabular}

TABLE IV Diagnosis

\begin{tabular}{|c|c|c|c|c|c|}
\hline Diagnosis & $\begin{array}{l}\text { Non-specific } \\
\text { infections }\end{array}$ & Gonorrhoea & $\begin{array}{l}\text { Trichomonal } \\
\text { vaginitis and } \\
\text { Candidiasis }\end{array}$ & Miscellaneous & $\begin{array}{l}\text { No sexually } \\
\text { transmitted } \\
\text { disease }\end{array}$ \\
\hline $\begin{array}{l}\text { Total number of patients } \\
\text { Mean score on questionnaire } \\
\text { Percentage potential psychiatric cases }\end{array}$ & $\begin{array}{r}64 \\
7 \cdot 3 \\
21 \cdot 9\end{array}$ & $\begin{array}{r}41 \\
8 \cdot 2 \\
24 \cdot 4\end{array}$ & $\begin{array}{l}21 \\
15 \cdot 3 \\
57 \cdot 2\end{array}$ & $\begin{array}{l}24 \\
11 \cdot 7 \\
37 \cdot 5\end{array}$ & $\begin{array}{l}69 \\
11 \cdot 2 \\
29 \cdot 0\end{array}$ \\
\hline
\end{tabular}

It can be seen that there is a consistent rise in score from Social Class I to Social Class IV, after which there are not enough cases to permit conclusions to be drawn. Students do not score differently from the group as a whole.

Table IV shows the variation of scores with venereological diagnosis. A one-way analysis of variance shows that the difference between the diagnoses is significant $(P<0.05)$. Those with the more typical, commonly occurring venereal diseases (nonspecific infections and gonorrhoea) appear relatively untroubled, and score significantly less than the others combined $(\mathbf{P}<0.001)$. Patients with trichomonal vaginitis and candidiasis score significantly higher when compared with all other groups taken together $(P<0.02)$. On the other hand those who had no sexually transmitted disease had scores within the average range for the whole group.

Table $\mathrm{V}$ shows the variation in scores according to presenting symptoms grouped into four categories: symptoms typical of venereal disease (such as urethral and vaginal discharge); no symptoms; complaints about the genitalia (such as marks and spots upon the genitalia); general systemic symptoms. Significantly lower scores $(P<0.01)$ are obtained by those with symptoms typical of venereal disease, a finding which corroborates that given in Table IV concerning diagnosis. Although it can be seen that the small group of patients with general symptoms scored higher than the others, the difference was not significant.

\section{TABLE V Symptoms}

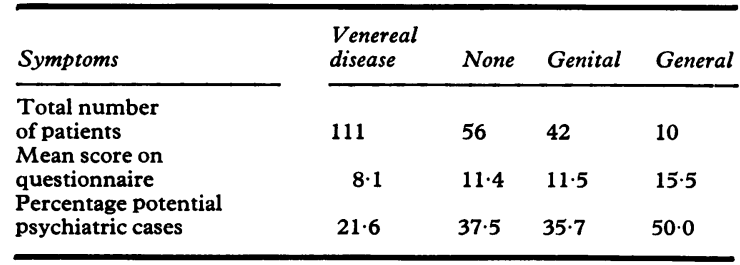


TABLE VI Sexual partner

\begin{tabular}{|c|c|c|c|c|c|c|c|}
\hline Sexual partner & Fiancée & Homosexual & Casual & Regular & Spouse & $\begin{array}{l}\text { Spouse } \\
\quad \text { Extra-marital intercourse }\end{array}$ & Prostitute \\
\hline Total number of patients & 7 & 12 & 68 & 81 & 27 & 8 & 6 \\
\hline
\end{tabular}

Table VI shows the variation in scores according to the sexual partners of the patients, who are so arranged that the percentage of probable psychiatric cases increases as the Table is read from left to right. Although it can be seen that the homosexual group has a low mean score, with a group of this size the difference just fails to reach significance. At the other end of the scale the percentage of potential psychiatric cases rises to as high as 50 pcr cent. in two small groups of patients (when the sexual partner was a prostitute and when both marital and extra-marital intercourse were reported), though again the numbers are too small to be significant.

A number of negative findings, which are not presented in tabular form, are nevertheless of some interest. There is no significant difference in the scores of the following groups of patients:

(i) Between 'contacts' and patients attending because of their own symptoms;

(ii) Between patients of different nationality;

(iii) Between patients with and without a past history of V.D.;

(iv) Between patients who had had their symptoms for different lengths of time;

(v) Between patients who had waited varying lengths of time since their last intercourse before coming to the clinic.

\section{Discussion}

The figures that have been given for the whole population of patients (mean score of 9.94 and percentage of probable psychiatric cases 29.7 per cent.) may seem surprisingly high, but they are comparable with those found in a general practice setting and a medical out-patients department using the GHQ (Goldberg, 1969). Similar figures have been obtained by using other methods of case identification among patients attending their general practitioner (Council of the College of General Practitioners, 1958) and among medical out-patients (Culpan, Davies, and Oppenheim, 1960). In a previous study in the same clinic (Pedder, 1970), the overall referral rate of psychiatric patients had been found to be very low $(0.3$ per cent.). One of the purposes of the present study was to investigate the relationship between this low referral rate and the actual incidence of psychiatric disturbance; it can now be seen that the low referral rate does not reflect a low incidence of psychiatric disturbance, but that for every case that is referred there are 99 other probable cases for whom help is not sought.

The higher mean GHQ scores in women than men are what one usually finds in psychiatric surveys. The increase in scores with age from 20 upwards confirms an earlier suggestion that affective disorders (mainly anxiety and depression) may be expected especially in the higher age groups, bringing patients to the venereology clinic with fears of venereal disease that are often unfounded. Such patients have often become depressed de novo, and developed fears of venereal disease because of guilt about present or past sexual fantasy or activity.

Scores were significantly lower in those with diagnoses of non-specific urethritis and gonorrhoea, and again in those with symptoms typical of venereal disease, such as urethral discharge or dysuria. Having straightforward venereal disease is therefore associated with a lower than average probability of psychiatric disturbance at the time of first attendance at a venereology clinic. It was surprising to find that scores were not significantly raised in the total group of those who had no sexually transmitted disease. One might have expected that this group would contain many people who were anxious about themselves, but if this is so they must be counterbalanced by others coming for a checkup who are not at all anxious. Put in another way, it appears to be no more disturbing for a patient to be told that he may have venereal disease and should attend as a contact than for him to develop symptoms of venereal disease and to seek help.

The low score of the homosexual group supports the view that, in general, many such patients are not overtly emotionally disturbed, and this fits in with the findings of others (Fluker, 1966; Pedder, 1970) concerning the low motivation for change in homosexuals attending venereology clinics.

\section{Summary}

The General Health Questionnaire (GHQ), which has recently been developed to estimate current psychiatric disturbance, was administered to consecutive new patients attending a venereology clinic 
in London. Scores were compared between different groups according to data extracted from the case notes.

Approximately 30 per cent. of the 219 patients who returned completed questionnaires were probable psychiatric cases, and it is noted that this figure is similar to that found in other settings, such as general practice and a medical out-patients department. Scores on the questionnaire were significantly lower in the cases of patients with gonorrhoea and nonspecific urethritis and those with presenting symptoms typical of venereal disease such as dysuria and urethral discharge. They were significantly higher in women than in men and particularly so in women with vaginal discharges due to candidiasis and Trichomonas vaginalis. Psychiatric disturbance was found to be no more common in patients without venereal disease who-attended the clinic than it was in the group as a whole. Attention is drawn to the increased expectancy of psychiatric disturbance among older patients.

The finding that about 30 per cent. of new patients were 'probable psychiatric cases' contrasts with the rate of referral for psychiatric investigation $(0.3$ per cent.) previously experienced in the same clinic, and indicates that for each patient referred there are likely to be many others for whom help is not sought.

We wish to express our gratitude to Dr. R. D. Catterall, Director of James Pringle House, for his encouragement of the project, and to all his staff whose co-operation made it possible. We are indebted to Mr. Frank Gattoni of the London School of Economics for his assistance with statistical aspects of the work and for kindly supervising the data on the survey programme of the LSE computer.

\section{References}

College of General Practitioners (1958). Brit. med. F., $2,585$.

Culpan, R. H., Davies, B. M., and Oppenheim, A. N. (1960). Ibid., 1, 855.

FlUKER, J. L. (1966). Brit. F. vener. Dis., 42, 48.

GibBens, T. C. N., and Silberman, M. (1960). Ibid., 36, 113.

GoldBerg, D. P. (1969). Thesis submitted for the degree of D.M., Oxford University.
Kite, E. DE C., and GRIMBLE, A. (1963). Brit. F. vener. Dis., 39, 173.

LINKEN, A. (1968). Ibid., 44, 337.

MACALPINE, I. (1957). Ibid., 33, 92.

PEDDER, J. R. (1970). Ibid., 46, .

Shepherd, M., CoOper, B., Brown, A. C., and Kalton, G. (1966). 'Psychiatric Illness in General Practice'. Oxford University Press, London.

Une enquête par questionnaire sur les troubles psychiâtriques présentés par les malades frequentant une clinique vénéréologique

\section{SOMMAIRE}

Un questionnaire de santé générale, le "General Health Questionnaire" (GHQ), utilisé récemment pour apprécier les troubles psychiâtriques courants, fut employé pour une série consécutive de nouveaux malades consultant dans une clinique vénéréologique de Londres. Les résultats furent comparés entre différents groupes selon les informations contenues dans les observations.

Environ 30 pour cent des 219 malades qui renvoyèrent les questionnaires remplis étaient probablement des cas psychiâtriques et l'on note que ce chiffre est semblable à celui que l'on trouve dans d'autres enquêtes: en clientèle générale ou chez les consultants des Services de médecine. Les réponses au questionnaire furent à un niveau significativement plus bas chez les malades atteints de gonococcie ou d'urétrite non spécifique que chez ceux présentant des symptômes typiques de maladie vénérienne, telles qu'une dysurie ou un écoulement urétral. Ils furent significativement à un niveau plus élevé chez les femmes que chez les hommes et, plus particulièrement, chez les femmes atteintes de leucorrhée due à la candidose ou au Trichomonas vaginalis. Les troubles psychiâtriques n'apparurent pas plus fréquents chez les sujets sans maladie vénérienne se présentant à la clinique que dans la population générale. On souligne que le risque de troubles psychiâtriques est plus grand chez les malades plus âgés.

Cette constatation, qu'environ trente pour cent des nouveaux malades représentaient des cas psychiâtriques probables, contraste avec le pourcentage des sujets adressés au psychiâtre pour étude ( 0,3 pour cent) auparavant noté dans la même clinique et indique qu'à côté des malades adressés au psychiâtre il en a apparemment beaucoup d'autres semblables parmi ceux pour qui une assistance psychiâtrique n'avait pas parue nécessaire. 